\title{
Digitalization of International Tax Dispute Resolution: Reflection in Light of the Covid-19 Pandemic
}

\author{
Qiang Cai ${ }^{*} \&$ Spyridon E. Malamis**
}

\begin{abstract}
The mutual agreement procedure (MAP) has long been criticized. From the perspective of transaction cost theory, the deficiencies of the mechanism primarily reflect three types of transaction costs: agency cost, bargaining cost, and administrative cost, all of which can be economized via the digitalization of international tax dispute resolution (ITDR) processes. The impetus for the development of digital ITDR becomes more prominent considering the current Covid-19 pandemic. Furthermore, compared with dispute resolution mechanisms in many other domains, the ITDR process particularly lends itself to digital facilitation. However, data from peer review reports under Action 14 of the Base Erosion and Profit Shifting (BEPS) Project shows that the international practice of the digital ITDR still remains at a rudimentary stage. This underdevelopment can largely be attributed to a decentralized approach to the ITDR development at the international level. In this regard, it is proposed that the OECD can play a greater role in leading and coordinating the development of digital ITDR at the global level. In particular, a global digital platform is envisaged to facilitate the digital ITDR processes among competent authorities.
\end{abstract}

Key words: Digitalization, international tax dispute resolution, online dispute resolution, Covid-19, new technologies, digital justice, mutual agreement procedure.

\section{INTRODUCTION}

Arguably, one thing that can be certain about people's life from the Covid-19 pandemic onwards is that life has been changed, probably permanently. Among others, social distancing may reinforce digitalization of the economy and life, a trend that has 
already been gaining ground in the past few decades. ${ }^{1}$ To illustrate, Zoom, one of the videoconferencing service providers, has witnessed a dramatic sudden explosion in the number of daily users, spiking to 200 million in March 2020 when an increasing number of countries imposed social distancing measures to contain the spread of the virus; this is compared with only 10 million in December of the previous year. ${ }^{2}$

Tax implications of digitalization have already been a high-profile topic for tax lawyers and were recently culminated in the Blueprint on Pillar One (hereinafter, blueprint) led by the Organisation for Economic Co-operation and Development (OECD). ${ }^{3}$ That being said, first and foremost, tax lawyers must adapt themselves to the new working mode in this 'distancing and digitalizing' environment. Challenges in this respect may include, inter alia, how to serve their clients, how to implement tax policies, and - relevant to this article - how to resolve tax disputes, particularly in the transnational context. Indeed, the prospect of the digitalization of international tax dispute resolution (ITDR) has already been envisioned in a few international documents. One example is the aforementioned blueprint report, which, in responding to the ongoing pandemic, recommends the use of conference calls, email exchanges, and secured virtual data rooms in the proposed tax certainty process. ${ }^{4}$ Another major example is the newly released United Nations (UN) Dispute Avoidance and Resolution Handbook (hereinafter, handbook) that contains a special section on the use of technology in the ITDR process. ${ }^{5}$

Nonetheless, the digitalization of the ITDR process has garnered very minimal attention in the academic circle even though online dispute resolution (ODR) or digital justice in a general context has long become a high-profile topic. ${ }^{6}$ For instance,

\footnotetext{
* Lecturer at the University of Aberdeen, Law School. Email: qiang.cai@abdn.ac.uk.

** An attorney at law, partner at S. Malamis \& E. Malamis Law Office (Athens, Greece); a holder of LL.M. in International Economic Law from the University of Edinburgh. Email: malamislaw@ gmail.com.

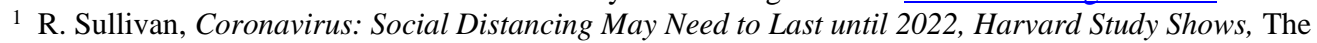
Independent (2020),

https://www.independent.co.uk/news/world/americas/coronavirus-social-distancing-2022-lockdown-update-a9466 036.html (accessed 19 Apr. 2020).

2 D. Evans, How Zoom Became so Popular during Social Distancing, CNBC (2020),

https://www.cnbc.com/2020/04/03/how-zoom-rose-to-the-top-during-the-coronavirus-pandemic.html (accessed 19 Apr. 2020).

3 OECD, Tax Challenges Arising from Digitalisation-Report on Pillar One Blueprint: Inclusive Framework on BEPS, OECD/G20 Base Erosion and Profit Shifting Project (OECD Publishing 2020).

${ }^{4}$ Ibid., at paras $753,754$.

${ }^{5}$ UN: Dispute Avoidance and Resolution Handbook (Projected Framework): Chapter 5: Tax Treaty Mechanisms to Resolve Cross Border Tax Disputes: The Mutual Agreement Procedure (2019),

https://www.un.org/development/desa/financing/document/dispute-avoidance-and-resolution-handbook-projectedframework-chapter-5-tax-treaty (accessed 4 Mar. 2021).

${ }^{6}$ For representative research, see M. E. Katsh \& O. Rabinovich-Einy, Digital Justice: Technology and the Internet of Disputes (Oxford University Press 2017); J. E. Cabral et al., Using Technology to Enhance Access to Justice, 26 HARV. JL \& TECH. 241 (2012); M. Velicogna, Justice Systems and ICT-What Can Be Learned from Europe, 3
} 
the recently published research on digital ITDR in this journal is that by Dimitropoulou et al. (published in two parts). ${ }^{7}$ The series envisions the prospect of applying modern, disruptive technologies - e.g. artificial intelligence (AI), shared-data platform, cloud-based solutions and blockchain - to improve the effectiveness of the ITDR process. ${ }^{8}$ The research is seminal not only for the vision of the most cutting-edge information and communication technologies (ICTs) applying to the ITDR but also in that the work begets further queries about aspects of digital ITDR that are more fundamental and theoretical. In particular, investigations can be conducted along the following lines:

- What is the general landscape of the digital ITDR system? Arguably, the technologies envisioned by Dimitropoulou et al. only concern the top part of the 'iceberg'.

- What are the pros and cons of digital ITDR? To address this question, both a general overview of digital justice and a critical examination of the ITDR process will be needed.

- Is the ITDR process more or less apt to digitalization, compared with other types of dispute resolution? The question is relevant because, after all, nearly all types of dispute resolution would benefit from digitalization in one way or another.

- What is the current state of the functioning of digital ITDR, and what would be the future?

The above queries form the heart of this article. In addressing these questions, the authors further purport to make some theoretical and methodological contributions to the existing literature. First, a transaction-cost framework will be employed for analysing the deficiencies of the ITDR process, thereby highlighting the aspects on which digitalization can make a difference. Under the traditional economic theory, the free market is generally assumed to be also cost-free and can automatically lead to overall efficiency for society. ${ }^{9}$ The idea had been so widely accepted until Ronald Coase raised a seminal question that decades later earned him a Nobel economic prize:

UTRECHT L. REV. 129 (2007).

7 C. Dimitropoulou, S. Govind \& L. Turcan, Applying Modern, Disruptive Technologies to Improve the Effectiveness of Tax Treaty Dispute Resolution: Part 1, 46 INTERTAX 856 (2018); Part 2, 46 INTERTAX 960 (2018).

8 Ibid.

9 E. G. Furubotn \& R. Richter, Institutions and Economic Theory: The Contribution of the New Institutional Economics 12 (2nd ed., University of Michigan Press 2010); T. Eggertsson, Economic Behavior and Institutions: Principles of Neoinstitutional Economics 14 (Cambridge University Press 1990). 
If market mechanism is so efficient in organizing social collaboration, why would firms and other types of economic organizations become necessary? ${ }^{10}$ The reason is, as Coase explained, that the use of a price mechanism implies transaction costs and firm helps to economize these costs. ${ }^{11}$ In a broader sense, transaction costs exist in the whole economic and social systems, including the costs 'of contracting and negotiating..., of measuring and policing property rights, of engaging in politics of power, of monitoring performances, and of organizing activities'. ${ }^{12}$ This definition highlights three major types of frictions that may create obstacles for the smooth operation of a society: agency problem (related to the costs of 'monitoring performances'), bargaining difficulty (concerning the costs of 'contracting and negotiating') and administrative burden (regarding the costs of 'organizing activities'). ${ }^{13}$ The transaction cost theory effectively extends the explanatory strength of an economic analysis from the market arena to wider legal and social areas. ${ }^{14}$ The digitalization of the dispute resolution process primarily concerns the management of the procedure rather than changing the nature of justice. Therefore, a managerial approach based on law-and-economic insight is tenable and beneficial.

Secondly, in assessing the current state of play regarding the ITDR process and its digitalization, the authors analyse 69 country reports produced from the peer review process endorsed in the Base Erosion and Profit Shifting (BEPS) Action 14. Launched by the OECD/G20 in 2013, the BEPS Project seeks to overhaul the current international tax rules mainly in response to aggressive tax planning by multinational enterprises. ${ }^{15}$ The project includes 15 actions, of which Action 14 aims to strengthen the ITDR process. ${ }^{16}$ To achieve this goal, the action institutes a peer review process to evaluate participating countries against the minimum standard of the mutual agreement procedure (MAP) - the major method of the ITDR - established in the action. The first round of peer review has already been embarked and has produced 69 country reports that provide a basis for assessing international practice on digital ITDR. ${ }^{17}$ The drafting of the peer review reports was mainly based on, inter alia,

\footnotetext{
${ }_{10}$ R. H. Coase, The Nature of the Firm, 4 ECONOMICA 386, 388 (1937).

11 Ibid., at 390-391.

12 S. N.S. Cheung, On the New Institutional Economics, in Contract Economics 48-65, 51 (L. Werin \& H. Wijkander eds., Blackwell 1992).

${ }^{13}$ Q. Cai, A Package Deal Is Not a Bad Deal: Reassessing the Method of Package Negotiation Under the Mutual Agreement Procedure, 46 INTERTAX 744, 745-748 (2018).

${ }^{14}$ C. Veljanovski, The Economics of Law 35-36 (2nd ed., Institute of Economic Affairs 2006).

15 OECD, OECD/G20 Base Erosion and Profit Shifting Project: Information Brief (OECD publishing 2015).

16 OECD, Making Dispute Resolution Mechanisms More Effective, Action 14 Final Report, 9 (OECD publishing 2015).

17 OECD: Action 14 - OECD BEPS, https://www.oecd.org/tax/beps/beps-actions/action14/ (accessed 28 Jan.
} 
- $\quad$ inputs provided by the assessed jurisdiction through the questionnaire;

- inputs from the peer questionnaires; and

- $\quad$ responses from the assessed jurisdiction to peer and taxpayer inputs. ${ }^{18}$

Therefore, the peer review reports provide an excellent window to assess countries' ITDR practice. By contrast, a traditional assessment in this regard was largely based on unpublished sources such as anecdotes or personal experiences due to the lack of transparency in the tax domain.

The remaining part of this article is organized as follows. Section 2 contains a critical review of countries' ITDR practices. Section 3 provides an overview of digital justice. Section 4 focuses on the ways that the ITDR process can be strengthened through digitalization. Section 5 explores special cases for the digitalization of the ITDR. In Section 6, the peer review reports under Action 14 will be analysed to assess the current state of play on the development of digital ITDR. In Section7, proposals on how to address the barriers to the development of digital ITDR will be submitted. Section 8 concludes.

\section{OVERVIEW OF ITDR PROCESSES}

\subsection{Outline of the ITDR contour}

Treaty-related tax disputes (hereinafter, 'tax disputes') are primarily dealt with through the MAP included in tax treaties, most of which follow the OECD or the UN Model Convention. ${ }^{19}$ Pursuant to Article 25 of both model conventions, if a taxpayer considers that the action of one or both contracting states has resulted in taxation not in accordance with the tax treaty provisions, he may submit the request for MAP assistance to the competent authority of either state. If the competent authority receiving the request (hereinafter, 'the first competent authority') is unable to resolve the dispute unilaterally, it should then approach the other competent authority (hereinafter, 'the second competent authority') for bilateral negotiation, and the two parties shall endeavour to resolve the dispute. ${ }^{20}$ The recommended timescale for a

2021).

18 OECD, BEPS Action 14 on More Effective Dispute Resolution Mechanisms Peer Review Documents, 23

(OECD publishing 2016).

19 C. Burnett, International Tax Arbitration, 36 Australian TAx REVIEW 173, 174 (2007).

20 OECD Model Convention (2017), Art. 25; UN Model Convention (2017), Art. 25. 
MAP is two years. ${ }^{21}$

In its 2008 update, the OECD Model Convention added an arbitration clause to Article 25 followed by the UN Model Convention in its 2011 update. Specifically, when the competent authorities are unable to resolve the dispute through the MAP within the prescribed timeframe, any unsettled issues can be resolved through the arbitration procedure. ${ }^{22}$ The ITDR procedure was further strengthened in the recent BEPS Project, mainly via Action 14; the multilateral instrument set forth in Action 15; and the UN Handbook. ${ }^{23}$ In particular, the access to the MAP has been widened and the arbitration procedure refined..$^{24}$

In the EU context, the Arbitration Convention was signed in 1990 instituting an arbitration procedure into the MAP. ${ }^{25}$ In 2017, the EU Council adopted the Arbitration Directive which supplements the Arbitration Convention in several major aspects. ${ }^{26}$ Among others, more clearly defined and enforceable timelines make the procedures more robust. ${ }^{27}$

More recently, the blueprint marked another paradigm shift in the ITDR by proposing a multilateral tax-certainty process. In short, the blueprint seeks to relocate a part of the residual profits to market jurisdictions irrespective of the existence of physical presence therein by establishing a new taxing right which is mainly reflected in Amount A. ${ }^{28}$ In order to ensure the certainty for the implementation of Amount A and other aspects of the new taxing right, the project institutes an innovative dispute prevention and resolution mechanism. ${ }^{29}$ In particular, the dispute prevention process will be facilitated by a representative panel performing reviewing functions and, when

\footnotetext{
${ }^{21}$ OECD, Manual on Effective Mutual Agreement Procedures (MEMAP), 31 (2007), http://www.oecd.org/ctp/dispute/manualoneffectivemutualagreementprocedures-index.htm (accessed 18 Mar. 2018); UN: Dispute Avoidance and Resolution Handbook (Projected Framework): Chapter 5: Tax Treaty Mechanisms to Resolve Cross Border Tax Disputes: The Mutual Agreement Procedure, supra n. 5, at para.52. 22 OECD Model Convention (2017), Art.25 (5).

23 OECD, Making Dispute Resolution Mechanisms More Effective, Action 14 Final Report, supra n. 16; Multilateral Convention to Implement Tax Treaty Related Measures to Prevent Base Erosion and Profit Shifting (MLI); UN, Dispute Avoidance and Resolution Handbook (Projected Framework): Chapter 5: Tax Treaty Mechanisms to Resolve Cross Border Tax Disputes: The Mutual Agreement Procedure, supra n. 5.

${ }^{24}$ OECD, Making Dispute Resolution Mechanisms More Effective, Action 14 Final Report, supra n. 16, at 9-13; MLI, Part V, VI.

25 90/463/EEC, Art.7.

26 Council Directive (EU) 2017/1852, Preamble.

27 Council Directive (EU) 2017/1852, Preamble. See also H. M. Pit, The Changed Landscape of Tax Dispute Resolution Within the EU: Consideration of the Directive on Tax Dispute Resolution Mechanisms, 47 INTERTAX 745 (2019); S. Govind, The New Face of International Tax Dispute Resolution: Comparing the OECD Multilateral Instrument with the EU Dispute Resolution Directive, 27 EC TAX REvIEw 309 (2018).

28 OECD, Tax Challenges Arising from Digitalisation-Report on Pillar One Blueprint: Inclusive Framework on BEPS, supra n. 3, at para.6.

${ }^{29}$ Ibid., at paras16-19.
} 
necessary, a determination panel to ensure the achievement of early certainty. ${ }^{30}$

Despite the legalistic trend in the ITDR development that is manifested in the increasing adoption of tax arbitration among countries, it is still safe to conclude that, by far, a vast majority of tax disputes have been finalized through the MAP. ${ }^{31}$ In particular, while the OECD had intended to promote a universal adoption of arbitration in tax treaties, the Action 14 Final Report notes that there is no consensus among all OECD and G20 countries on the initiative. ${ }^{32}$ While many tend to attribute the under-adoption of tax arbitration to countries' sovereignty concern, the fact that the resistance towards the mechanism overwhelmingly exists among developing countries indicates resource deficit and/or capacity constraint may be the real hurdle for the wider promotion of tax arbitration. ${ }^{33}$

\subsection{Transaction-cost framework for ITDR}

While the MAP is generally accepted as an effective way of resolving a majority of tax disputes, its inadequacies have long been a target of intensive criticisms. ${ }^{34}$ The procedure is often perceived to be time-consuming, with no guarantee of finality. It is also criticized for a lack of transparency as the procedure primarily takes place between the two competent authorities with the concerned taxpayer largely excluded from the process. Many also concern the procedure's accessibility as tax treaties generally mandate the competent authority to determine the eligibility of a MAP request. A potential fear is that competent authorities may abuse this discretion with a view to barring the procedure from the very beginning. The advantages and disadvantages of the MAP can be viewed through the lens of the transaction-cost framework

\subsubsection{Agency problem}

A principal-agency relation exists when one party (the principal) delegates certain work to another (the agent). Such relations pervade modern society such as those of

\footnotetext{
30 Ibid., at paras 705, 706 .

31 Burnett, supra n. 19, at 174.

32 OECD, Making Dispute Resolution Mechanisms More Effective, Action 14 Final Report, supra n. 16, at 41.

${ }_{33}$ Q. Cai, Behind Sovereignty: Concerns About International Tax Arbitration and How They May Be Addressed, BRITISH TAX REVIEW 441 (2018); M. Lennard, International Tax Arbitration and Developing Countries, in International Arbitration in Tax Matters 179-188 (Michael Lang \& Jeffrey Owens eds., IBFD 2015).

34 J. Kollmann \& L. Turcan, Overview of the Existing Mechanisms to Resolve Disputes and Their Challenges, in INTERNATIONAL ARBITRATION IN TAX MATTERS 15-78, 25-32 (M. Lang \& J. Owens eds., IBFD 2015); L. B Terr et al., Resolving International Tax Disputes: APAs, Mutual Agreement Procedures, and Arbitration, 41 TAX MANAGEMENT INTERNATIONAL JouRnAL 435, 471-482 (2012); Burnett, supra n. 19, at 178-180.
} 
worker-boss, physician-patient, landlord-tenant, and so on. ${ }^{35}$ The central problem of the agency relation is that the agent may pursue its own interest rather than being loyal to the principal. ${ }^{36}$ In the ITDR setting, while the main goal of tax treaties is to eliminate double taxation for taxpayers, MAP processes are dominated by competent authorities who are typically affiliated to national tax administrations. ${ }^{37}$ It follows that an agency relationship exists in a MAP process - with the competent authorities being the agent and the taxpayer principal - and the agency problem may ensue. ${ }^{38}$ Specifically, the tax administrations may prioritize the goal of revenue collection over the timely resolution of tax disputes. Accordingly, they may fail to exercise due diligence or even strategically block the procedure if either of them feels that the pursuit of the procedure may jeopardize their fiscal interests. ${ }^{39}$

\subsubsection{Bargaining difficulty}

Even assuming two competent authorities enter a MAP in good faith, the negotiation may still go awry as the parties may find difficulties in agreeing on how to distribute the stake at issue..$^{40}$ This bargaining difficulty can be further exacerbated by the complexity of the dispute in question. ${ }^{41}$ Distributive conflicts in tax disputes are prevalent, with one state's fiscal gain being the other's loss. Also prominent is the complexity of tax disputes, which, as perceived by the US Federal Courts Study Committee, is 'one of the most specialized and technically demanding fields'. ${ }^{42}$ Consequently, significant delay or outright breakdown may occur to MAP cases due to those bargaining difficulties.

\subsubsection{Administrative burden}

To be sure, most positive comments about the MAP, if any, are focused on the

\footnotetext{
35 Eggertsson, supra n. 9, at 40-41; B. M. Mitnick, The Theory of Agency: The Policing 'Paradox' and Regulatory Behavior, PUBLIC CHOICE 27, 41 (1975).

36 EgGeRTSSON, supra n. 9, at 40-41.

37 OECD, MEMAP, supra n. 21, at 7, 39.

38 Q. Cai \& P. Zhang, A Theoretical Reflection on the OECD's New Statistics Reporting Framework for the Mutual Agreement Procedure: Isolating, Measuring, and Monitoring, 21 JOURNAL OF INTERNATIONAL ECONOMIC LAW 867, 874-875 (2018).

${ }^{39}$ Ibid.

${ }^{40}$ Cai, supra n. 13, at 746-747.

41 J. Kim \& J. T. Mahoney, Property Rights Theory, Transaction Costs Theory, and Agency Theory: An Organizational Economics Approach to Strategic Management, 26 MANAGERIAL AND DECISION ECONOMICS 223, 235 (2005).

${ }^{42}$ Federal Courts Study Committee (US), Report of the Federal Court Study Committee, 70 (1990), https://www.fjc.gov/content/report-federal-courts-study-committee-0 (accessed 28 Jan. 2021).
} 
procedural flexibility of the mechanism as opposed to tax arbitration or adjudication. That being said, the procedure still incurs substantial administrative costs. As the Manual on Effective Mutual Agreement Procedures (MEMAP) notes, the procedure needs sufficient human (skilled personnel), financial (in particular to pay for translations and travel/accommodation expenses for face-to-face meetings with other competent authorities) and other resources (access to company databases, industry data and foreign tax laws) to be able to meet its obligations under the Convention. ${ }^{43}$

Such administrative burden may become particularly burdensome for those least developed countries that may suffer from a shortage of key resources in handling tax disputes. $^{44}$

\subsection{ITDR practice in peer review reports ${ }^{45}$}

The peer review reports of the first stage mainly focus on three parts:

- the access to the MAP;

- the resolution of MAP cases, which mainly concerns countries' endeavours in seeking to resolve cases within a 24-month time frame, and their working relationships with their peers; and

- the implementation of MAP agreements.

\subsubsection{Access to the MAP}

Taxpayers in the vast majorities of countries that are being reviewed possess easy access to the MAP. Many countries rejected no $^{46}$ or very few ${ }^{47}$ MAP requests during the assessed period. Nonetheless, several countries seem to have a relatively strict

\footnotetext{
43 OECD, MEMAP, supra n. 21, at 39.

44 Dimitropoulou, Govind \& Turcan, supra n. 7, at 858.

${ }^{45}$ S. 2.3 has largely been adapted from Q. Cai, Economising International Tax Dispute Resolution: Transaction-Cost Perspective (doctoral Thesis), 162-174 (2020).

${ }^{46}$ For example, see OECD: Action 14 - OECD BEPS, supra n.17, reports on Canada (paras 26-50), Chile (paras 40-68), Colombia (paras 6-30), Czech Republic (paras 42-70), Estonia (para.28), Greece (paras 46-75), Hungary (paras 46-76), Iceland (paras 35-60), Ireland (paras 41-72), Japan (paras 44-75), Korea (paras 44-71), Latvia (paras 35-64), Lithuania (paras 40-77), Malta (paras 41-70), Mexico (paras 42-73), New Zealand (paras 43-72), Romania (paras 40-67), Saudi Arabia (paras 27, 28), Singapore (paras 38-67), Slovak Republic (paras 44-72), South Africa (paras 38-69), Switzerland (paras 21-45), Turkey (paras 42-74), and UK (paras 26-50).

47 For example, reports on Austria (paras 26-53), Belgium (paras 28-49), Finland (paras 38-65), Luxemburg (paras 21-44), Norway (paras 37-64), Portugal (paras 42-79), Slovenia (paras 48-81), Sweden (paras 30-56), and the US (paras 31-59).
} 
standard regarding the access to the MAP. ${ }^{48}$ Several countries' practices have attracted substantial criticisms from peers/taxpayers. For example, in Australia, Germany, and Italy, taxpayers were allegedly compelled by the relevant tax administrations to waive their access to the MAP in advance in exchange for a relatively favourable audit settlement. ${ }^{49}$ In Denmark, the competent authority denied the access to four MAPs citing the reason of insufficient information. Three of the cases were then appealed by the concerned taxpayers to the Danish Western High Court, and the court ruled for the complainants. ${ }^{50}$

\subsubsection{Resolution of MAP cases}

A majority of countries received overall positive comments from peers on this aspect. A significant number received high commendation from peers. ${ }^{51}$ That being said, some received mixed ${ }^{52}$ or quite negative ${ }^{53}$ feedback from peers. The negative comments were centered on several major aspects. First, many countries, even including some of those commended countries, were reported that their competent authorities had not always met the expected timeframe for certain intermediate steps of MAP processes, such as presenting a position paper or responding to such a paper. ${ }^{54}$ Peers further noted that certain countries' lack of responsiveness was particularly notable in the cases for which the adjustments were made by their tax administration. ${ }^{55}$ Second, numerous jurisdictions were reported by peers that their competent authorities tended to take a rigid stance in negotiations. ${ }^{56}$ For some, this rigidity reflected the competent authorities' lack of independence from the audit departments. ${ }^{57}$ On other occasions, the bargaining deadlock seemed to result from the

\footnotetext{
${ }^{48}$ For example, see reports on France (paras 25-48), Israel (paras 42-72), the Netherlands (paras 22-52), and Poland (paras 35-62).

${ }^{49}$ Reports on Australia (paras 69, 70), Germany (para.65), and Italy (paras 58, 59).

50 Report on Denmark (paras 72,73).

${ }^{51}$ For example, see reports on Australia (para.140), Canada (para. 140), Ireland (para.128), Japan (paras 172-176), The Netherlands (paras 93, 94), New Zealand (para.127), Switzerland (para.80), the UK (para.95), and the US (para.95).

52 For example, see reports on France (paras 99, 100), Hungary (para.135), India (para.159), Korea (para.125), Mexico (paras 139-141), Poland (para.115), and Russia (paras 139-143).

${ }^{53}$ For example, see reports on Greece (para.132) and Italy (para.116).

${ }^{54}$ For example, see reports on Argentina (para. 134), Belgium (para. 114), Canada (para. 93), Colombia (para.83), Czech Republic (paras 115, 128), Denmark (para.146), Finland (paras 135, 137), France (paras 100, 101), Germany (paras 139, 140), Greece (paras 132-134), Hungary (paras 135, 136), India (paras 170-176), Italy (paras 118-120, 143), Korea (paras. 143), Luxembourg (para. 89), Mexico (paras 139, 141, 153), Norway (paras 116, 129), Poland (paras 115, 126), Portugal (para.137), Russia (paras 139-143), Saudi Arabia (para. 113), and Spain (paras 141, 143, 145).

${ }^{55}$ For example, see reports on Canada (para. 93) and Italy (para.143).

${ }^{56}$ For example, see reports on Australia (para.141), Canada (para.93), Czech Republic (para. 128), Germany (paras 147, 150), Hungary (para. 137), India (para.182), Italy (para.117), Korea (para. 149), Poland (para.127), Spain (para.147), and Sweden (para. 117).

${ }^{57}$ For example, see reports on Germany (paras 147, 150).
} 
complexity of the case. ${ }^{58}$ Thirdly, numerous jurisdictions left an impression on peers that their competent authorities were not equipped with adequate resources and hence impeded the expeditious resolution of MAP cases. ${ }^{59}$

\subsubsection{Implementation of MAP agreements}

In general, peers and taxpayers are satisfied with the assessed jurisdictions on the timely implementation of MAP agreements once it is reached. Only a few jurisdictions reported that a small number of cases took longer than the usual time for implementation. ${ }^{60}$

\subsubsection{Interim conclusion}

From the peer review reports, it can be seen that the assessment on the countries' MAP practice is mixed. On the one hand, a majority of MAP cases have been handled satisfactorily. On the other hand, the inadequacies of the mechanism are more than noticeable. The bleak side of MAP practice reflects the transaction costs of the mechanism. Specifically, the obstruction of access to the MAP and the lack of response from the relevant competent authorities largely reflect its agency problem. Distributive conflict and the complexity of tax disputes exacerbate the bargaining problem between competent authorities. In many other cases, a delay of the processes results from staff shortage or other types of resource constraint that reflect the administrative costs of the MAP.

To be sure, the recent legalistic reform of the ITDR featuring the institution of tax arbitration into the MAP may mitigate the transaction costs of the MAP. Specifically, in the sense that an arbitral panel will take over the procedure and be bound to issue a binding arbitral decision, both the agency and bargaining problems of the MAP can be mitigated. Indeed, it is widely believed that the major function of tax arbitration is to spur competent authorities to resolve MAPs in a timely manner. ${ }^{61}$ Nonetheless, the administrative costs of the arbitration process will generally be higher than the MAP. Studies on the procedural costs of commercial arbitration abound. ${ }^{62}$ A general

\footnotetext{
${ }^{58}$ For example, see reports on Finland (para. 135), Germany (para. 146), Japan (para. 172), Korea (para.149), and The Netherlands (para. 94).

${ }^{59}$ For example, see reports on France (para. 115), India (paras 179, 181), Italy (para.134), Norway (para. 129), Poland (para. 127), and Russia (para. 144).

${ }^{60}$ For example, see reports on Finland (para.163), France (para.145), Italy (para.160) and Saudi Arabia (para. 139).

${ }^{61}$ Kollmann and Turcan, supra n. 34, at 37; Terr et al., supra n. 34, at 493.

${ }^{62}$ For representative work in this regard, see ICC, Techniques for Controlling Time and Costs in Arbitration (2012),
} 
perception is that commercial arbitration processes, particularly those in a transnational context, are becoming increasingly expensive and time-consuming. ${ }^{63}$ This cost may particularly burden developing countries as opposed to developed countries and therefore explains, at least partially, the developing countries' resistance towards the adoption of arbitration in their tax treaties. ${ }^{64}$ Therefore, arbitration should not be taken as a panacea to the deficiencies of the MAP. By contrast, as the UN handbook recognizes, the issue of resource constraint makes ITDR processes particularly amenable to digital solutions. ${ }^{65}$

\section{OVERVIEW OF DIGITAL JUSTICE}

\subsection{Brief sketch of historic development}

As early as the 1990s, many courts in developed countries began to substantially invest in ICT hardware and software. ${ }^{66}$ Nevertheless, the level of the ICT being used was rudimentary and mostly limited to word processing and information storage; and the major focus was to improve certain administrative aspects of dispute-resolution processes. ${ }^{67}$ Since the beginning of the 21 st century, ICT has changed dramatically, featuring an unprecedented capability for data processing and interchange as well as the growing popularity of the internet and digital communication. These changes have considerably transformed dispute resolution and justice. ICTs that are more advanced, such as the case management system and videoconferencing, have been introduced into dispute-resolution processes. ${ }^{68}$ In particular, the advent of the ODR became a game changer in transferring the entire dispute resolution process online. In 1999, eBay placed a link on its customer service page informing users that they could obtain the service of an online alternative dispute resolution (ADR) by clicking on the link and filling a complaint form that would be submitted to an experienced mediator. ${ }^{69}$

\footnotetext{
https://iccwbo.org/publication/icc-arbitration-commission-report-on-techniques-for-controlling-time-and-costs-in-a rbitration/; ICC, Effective Management of Arbitration-A Guide for In-House Counsel and Other Party Representatives,

https://iccwbo.org/publication/effective-management-of-arbitration-a-guide-for-in-house-counsel-and-other-party-r epresentatives/; D. W. Rivkin \& S. J. Rowe, The Role of the Tribunal in Controlling Arbitral Costs, 81 ARBITRATION 116 (2015).

${ }^{63}$ A. B. A. Journal, International Arbitration Loses Its Grip ABA JoURNAL, http://www.abajournal.com/magazine/article/international_arbitration_loses_its_grip/ (accessed 5 May. 2018).

${ }^{64}$ Cai, supra $\mathrm{n} .33$, at 443.

${ }^{65}$ UN: Dispute Avoidance and Resolution Handbook (Projected Framework): Chapter 5: Tax Treaty Mechanisms to Resolve Cross Border Tax Disputes: The Mutual Agreement Procedure, supra n. 5, at para.214.

${ }^{66}$ Velicogna, supra n. 6, at 131.

67 Katsh \& Rabinovich-Einy, supra n. 6, at 155.

${ }^{68}$ Id. at 33; Cabral et al., supra n. 6, at 244.

${ }^{69}$ Katsh \& Rabinovich-Einy, supra n. 6, at 32.
} 
Other world-famous ODR initiatives include, inter alia, Cybersettle, Domain Names, and the World Intellectual Property Organization (WIPO) - the WIPO is a self-funding agency of the United Nations with 193 Member States. ${ }^{70}$ While most ODR services were originally launched to address conflicts that arose online - mostly related to e-commerce or online social interaction) - their potential has also been increasingly recognized in the resolution of offline disputes. ${ }^{71}$

More recently, a number of cutting-edge technologies, - e.g., big data, block chain, and $\mathrm{AI}$ - seem to mark a new paradigm of ICT development. A major commonality of these modern disruptive technologies is their decision-making and entrepreneurial functions, such as AI arbitrator or big data analysis for case management purposes. ${ }^{72}$ The use of these modern disruptive technologies to dispute resolution processes has garnered substantial interests, albeit with growing uneasiness about their moral and equitable repercussions. ${ }^{73}$

\subsection{Basic components of digital justice and their implications for ITDR}

According to different functions of ICTs in dispute-resolution processes, three basic components of digital justice can be identified. ${ }^{74}$

\subsubsection{Stand-alone ICT tools.}

Stand-alone ICT tools assist in the execution of discrete tasks in dispute resolution. They range from basic technologies such as word processing and internet access to more advanced courtroom technologies such as audio and video equipment used to present digital evidence or written arguments. ${ }^{75}$ As basic as they are, these stand-alone tools excel in their capability for data processing and storage in comparison to human power, thereby opening up enormous opportunities to automate dispute-resolution processes. ${ }^{76}$ Typically, these technologies are not specific to any particular dispute-resolution setting, and many of them can be acquired from the

\footnotetext{
${ }^{70}$ See websites of Cybersettle, http://www.cybersettle.com/ (accessed 21 Apr. 2021); WIPO, https://www.wipo.int/amc/en/ (accessed 21 Apr. 2021). See also K. Mania, Online Dispute Resolution: The Future of Justice, 1 INTERNATIONAL COMPARATIVE JURISPRUDENCE 76, 77 (2015).

71 Katsh \& Rabinovich-Einy, supra n. 6, at 38.

72 Ibid., at 38 .

73 Ibid., at 48-51.

74 D. Reiling, Technology for Justice: How Information Technology Can Support Judicial Reform 50-59 (Leiden University Press 2009); Velicogna, supra n. 6, at 131-145.

${ }^{75}$ Katsh \& Rabinovich-Einy, supra n. 6, at 155; Reiling, supra n. 74, at 50-51.

76 Velicogna, supra n. 6, at 133.
} 
market. ${ }^{77}$ Therefore, it is reasonable to infer that a competent authority's access to such general technology mainly depends on the country's IT capability. In this regard, the digital inequality among countries comes to the fore. The World Bank reports that at the end of 2019, half of the world population was still without internet access with the vast majority concentrated in developing countries. ${ }^{78}$

\subsubsection{Digital communication system}

Digital communication systems deal with data interchange among the participants of a dispute-resolution process. Examples include online filing, online notification, videoconferencing, and other digital means of information exchange. ${ }^{79}$ At a more advanced level, the entire dispute resolution process can be carried out online, such as the abovementioned ODR project. This communication component enables parties to overcome those long-established constraints imposed by time and space in traditional dispute-resolution settings. For example, due to the help of ICTs, many courts are now able to be 'open 24 hours a day, 7 days a week, both for the consultation and for submission of documents' ${ }^{80}$ In the ITDR context, one example of an advanced digital communication system is a secured cloud server envisioned by the UN handbook and the article by Dimitropoulou et al. Through this digital platform, taxpayers and competent authorities can upload the documents that they wish to share. ${ }^{81}$

\subsubsection{Digital case management system}

Case management involves the managing and monitoring of cases from the time an action is filed to the moment it is settled. It ensures that cases are disposed properly and promptly. ${ }^{82} \mathrm{~A}$ digital case management system may integrate the digital communication systems and basic ICT tools mentioned above, yet the focus is more on entrepreneurial functions of the technologies. For instance, such a system can compile and analyse the aggregate information about a group of cases and the workload of a dispute-resolution body. This overall analysis can be used to evaluate whether resources such as adjudicators, staff, time, and courtrooms have been

\footnotetext{
77 Ibid., at 131

78 Overview, WoRLD BANK, https://www.worldbank.org/en/topic/digitaldevelopment/overview (accessed 6 Mar. 2021).

${ }^{79}$ Velicogna, supra n. 6, at 137.

${ }^{80}$ Ibid., at 141.

${ }^{81}$ UN: Dispute Avoidance and Resolution Handbook (Projected Framework): Chapter 5: Tax Treaty Mechanisms to Resolve Cross Border Tax Disputes: The Mutual Agreement Procedure, supra n. 5, at para. 218; Dimitropoulou, Govind \& Turcan, supra n. 7, at 866-867.

${ }^{82}$ Velicogna, supra n. 6, at 135.
} 
allocated and used efficiently. ${ }^{83}$ Arguably, ICT-based case management tools would be particularly useful for ITDR processes considering the heavy caseload facing many competent authorities.

\subsubsection{ICTs for decision making}

ICT-based decision making touches the very essence of adjudicative activities. A typical example of decision-making ICTs is the sentencing information system launched in numerous countries. ${ }^{84}$ Under this system, standard decision models for sentencing are programmed in a computerized system based on the data of previous trial practices. Once the system is fed with relevant facts of a particular offence, a range of sentences and penalties that allegedly match the severity of the offence are retrieved. ${ }^{85}$ More recently, the development of modern disruptive technologies such as AI, big data, and block chain has shown vast potential to further transform adjudicative activities. A common feature of these advanced technologies is the use of algorithms, which are instructions that tell a computer what to do. ${ }^{86}$ When chained together, they become more intelligent and entrepreneurial. ${ }^{87}$ Consider Airbnb's decisions on which rentals to display or Google's decision on the order for displaying search results. They are only a few examples of algorithm applications. ${ }^{88}$ In the ITDR context, the prospect of using AI and big data in assisting the substantive assessment of tax disputes has been considered in the research by Dimitropoulou et al. ${ }^{89}$

\subsection{Governance on digital justice}

Despite its obvious advantages, digital justice has raised serious concerns. One issue relates to the interest of confidentiality that has traditionally been considered an essential element for ADRs. ${ }^{90}$ In a similar vein, the ITDR process, particularly the MAP, features a high degree of confidentiality. ${ }^{91}$ The facts of a tax dispute may

\footnotetext{
83 Ibid., at 135 .

${ }^{84}$ Ibid., at 137.

85 Ibid., at 137; M. L. Miller, Sentencing Reform Reform: The Sentencing Information System Alternative to Sentencing Guidelines, AVAILABLE at SSRN 404981 (2004); I. Potas et al., Informing the Discretion: The Sentencing Information System of the Judicial Commission of New South Wales, 6 InTERnATIONAL JOURnAL OF LAW AND INFORMATION TECHNOLOGY 99 (1998).

86 T. Greene, A Beginner's Guide to AI: Algorithms The NeXT WeB (2018), https://thenextweb.com/artificial-intelligence/2018/08/02/a-beginners-guide-to-ai-algorithms/ (accessed 5 Apr. 2019).

87 Ibid.

${ }^{88}$ Katsh \& Rabinovich-Einy, supra n. 6, at 48.

${ }^{89}$ Dimitropoulou, Govind \& Turcan, supra n. 7, at 863-865.

90 E. Reymond-Eniaeva, Towards a Uniform Approach to Confidentiality of International Commercial Arbitration (1st ed., Springer International Publishing 2019).

91 Terr et al., supra n. 34, at 473-475.
} 
contain important information about the taxpayer's business or financial details that the taxpayer would rather keep secret. ${ }^{92}$ A problem with digital justice is that any communication taking place in cyberspace can easily be recorded, and the transmission or dissemination of such records is extremely easy. This raises a concern that confidential materials of disputes might be disclosed by participants (parties, legal counsel, adjudicators, supporting staff, etc.) of the cases in an impropriate manner or hacked by outsiders..$^{93}$

Another concern is related to the value of due process, particularly with respect to the use of AI in the process of dispute resolution. Specifically, it has been a concern that AI may accentuate existing discrimination by aggregating or classifying data related to persons or groups of persons. It may also cause a 'black-box-effect' that would make it impossible to check how a certain result was reached by the AI tools. ${ }^{94}$ Considering the sensitivity of international tax disputes - taxation has traditionally been seen as the blood of sovereignty - this black-box-effect may only undermine countries' faith towards a global cooperation in the ITDR.

Recognizing the above challenges, the European Commission sets out guidelines on digital justice along several dimensions including, inter alia, non-discrimination, privacy and data protection, and transparency. ${ }^{95}$ Similar challenges and concerns have arisen elsewhere in the world. A notable example relates to New York City where a law on algorithmic decision-making was introduced for the first time. The law set up a task force to monitor the validity and equitability of the algorithms by the municipal agencies. ${ }^{96}$

\footnotetext{
92 S. Castagna, The Benefits of Differentiated Transparency. Proposal for Graduated Confidentiality Regimes within International Tax Disputes, 48 INTERTAX 1125, 1125-1127 (2020).

${ }_{93}$ G. Kaufmann-Kohler \& T. Schultz, The Use of Information Technology in Arbitration, JusLETTER DECEMBER, para. $192(2005)$.

94 European Council, Digital Justice: Council Adopts Conclusions on Digitalisation to Improve Access to Justice, paras 39-45,

https://www.consilium.europa.eu/en/press/press-releases/2020/10/13/digital-justice-council-adopts-conclusions-on -digitalisation-to-improve-access-to-justice/ (accessed 17 Mar. 2021); see also T. Sourdin, Judge v. Robot: Artificial Intelligence and Judicial Decision-Making, 41 UNSWLJ 1114 (2018); A. Završnik, Criminal Justice, Artificial Intelligence Systems, and Human Rights, 20 ERA FoRUM 567-583 (Springer 2020).

95 European Council, Digital Justice: Council Adopts Conclusions on Digitalisation to Improve Access to Justice, supra $\mathrm{n} .94$.

96 New York City Council: Automated decision systems used by agencies (2018/049), https://legistar.council.nyc.gov/LegislationDetail.aspx?ID=3137815\&GUID=437A6A6D-62E1-47E2-9C42-46125 3F9C6D0 (accessed 14 Mar. 2021). Završnik, supra n. 94, at 579.
} 


\section{TRANSACTION-COST ANALYSIS OF DIGITAL ITDR}

\subsection{Administrative aspect}

Arguably, one of the most obvious benefits of ICT is to ease the administrative burden of dispute-resolution processes. Several ways for ICTs to economize the administrative costs of the ITDR can be envisaged. First, those mundane activities involved in the process, such as the registration of MAP requests, the compilation of statistics, and the production of standardized documents, can be automated by ICT tools. For example, the MEMAP acknowledges that the electronic submission of MAP requests can be helpful in encouraging simultaneous delivery of information to the two competent authorities. It may also ease the burden of submission for the taxpayer while facilitating the administration of such requests by the competent authority. ${ }^{97}$

Second, the use of digital means of communication, particularly audio- or videoconferencing, can overcome the physical constraints facing ITDR processes. For example, while tax authorities in many countries prefer face-to-face meetings over written correspondences as an effective means of communication in MAP processes, many also acknowledge that overseas travel often stretches their budget. ${ }^{98}$ Now, due to the pandemic, overseas travel and in-person meetings may further raise the concern of health risks.

Third, the use of ICT-based case management systems can help competent authorities manage various procedural requirements and deadlines of pending cases. Problematic cases, such as those with substantial delays or disagreements, can be identified so that one or both competent authorities can develop specific plans to address the possible impediments. ${ }^{99}$ Such systems can also monitor the workloads of a competent authority and its staff members as well as indicate optimal ways of allocating resources within it.

In a more entrepreneurial way, the system can conduct an overall analysis of the substantive aspects of tax disputes and identify the patterns of the past and pending disputes. This 'pattern research' is instrumental for the method of batch negotiation

\footnotetext{
97 OECD, MEMAP, supra n. 21, at 16.

98 OECD: Action 14 - OECD BEPS, supra n.17, reports on Australia (para.155), Belgium (para.105), Canada (para.109), and the UK (para.108).

99 See OECD, MEMAP, supra n. 21, at 28.
} 
whereby two competent authorities resolve several cases at the same time. Batch negotiation saves the costs of time and expertise since, for MAPs sharing a common fact pattern, there are fewer needs for competent authorities to 'reinvent the wheel' for each of the cases. ${ }^{100}$ Pattern research is also helpful for dispute avoidance so that costs in relation to future tax disputes can also be saved.

Lastly, more-advanced ICTs that are more advanced such as AI may assist competent authorities, third-party neutrals, and legal counsel involved in the ITDR processes to make decisions on tax cases.

\subsection{Agency aspect}

According to the agency theory, the opportunistic inclination of competent authorities in ITDR processes is positively related to two major factors. The first is interest divergence. ${ }^{101}$ If those authorities care more about revenue maximization than about the elimination of double taxation, they would be less motivated to pursue timely resolution of tax disputes, and more inclined to 'shirk' in the process or even play statesmanship. The second factor is information asymmetry. ${ }^{102}$ The competent authorities dominate the MAP process, thereby having more information about the process than the concerned taxpayer. This information asymmetry increases the difficulty for the taxpayer to monitor those authorities who may accordingly be more encouraged to behave in an opportunistic manner.

Both of the two factors, i.e., interest divergence and information asymmetry, lend themselves to ICT solutions. First, insofar as technology substitutes for humans, the issue of mismatched incentives can be mitigated. Although science fiction has envisioned AIs with self-consciousness, ${ }^{103}$ in real life, it is generally safe to assume that technology is always 'loyal' to its human employer. Second, ICT enables a principal to gain simpler and less expensive access to the information both about the task assigned to the agent and about the agent's performance. Lastly, ICT enables the principal to monitor the agent more effectively and efficiently.

In the ITDR context, various means of economizing agency costs of dispute-resolution processes can be incorporated into an ICT-based management

\footnotetext{
100 Cai, supra n. 13, at 748.

101 K. M. Eisenhardt, Agency Theory: An Assessment and Review, 14 ACADEMY OF MANAGEMENT REVIEW 57, 62 (1989).

102 Ibid. at 60.

${ }^{103}$ For example, see N. Kritzer, Cat Pictures Please, Clarkesworld Magazine, 2015.
} 
system. In the first place, the system can provide structured and automated means for taxpayers to launch MAP cases. A taxpayer can file a MAP request with the system and upload supporting documents following programmed steps. Once these online steps are completed, the taxpayer would normally be regarded as having provided sufficient information for its MAP request. Hence, access to the MAP cannot be denied on the grounds of insufficiency in information provision. In this way, the competent authorities' discretionary power over the admissibility of MAP requests can be effectively tamed.

After a MAP request is accepted, the system would monitor the timeline of the ITDR process even including the time spent on the intermediate steps within the process. Missed deadlines would be communicated to the relevant competent authorities, or, in more serious cases, to all other peers via the peer review process in Action 14. Moreover, information about the progress of individual MAP cases would be available to the taxpayers concerned or any other affected persons. Indeed, taxpayer participation in itself imposes monitoring pressure on competent authorities and thereby mitigates the agency problem of MAPs. However, a major concern is that greater taxpayer participation may increase administrative burden for competent authorities handling MAP processes. In this connection, digital ITDR may facilitate a more cost-efficient taxpayer participation.

Overall, the system would periodically assess the performance of competent authorities and their staff based on indicators such as the average time taken for the completion of MAP cases. The result of the assessment would be fed into the human resource management system of the competent authority. In this way, the incentive of competent authorities and their staff members can be better aligned with the goal of eliminating double taxation that is enshrined in tax treaties.

\subsection{Bargaining aspect}

According to bargaining theories, two major factors play a pivotal role in contributing to the bargaining difficulty of MAPs: distributive conflict ${ }^{104}$ and the complexity of the cases. ${ }^{105}$ These two factors can be addressed, at least partially, using ICT solutions. Specifically, an AI expert envisioned above (Section 3.2 (4)) can help competent

104 G. D. Libecap, Contracting for Property Rights 116 (Cambridge university press 1993); R. H. McAdams, Beyond the Prisoners' Dilemma: Coordination, Game Theory, and Law, 82 S. CAL. L. Rev. 209, 215 (2008).

105 Kim and Mahoney, supra n. 41, at 235. 
authorities to develop a higher degree of mutual understanding on technical and complicated issues of tax disputes and adopt a more realistic viewpoint about their cases. In particular, an 'AI mediator' can be envisioned to provide non-binding opinions on MAP cases to competent authorities. The role of mediation in addressing bargaining difficulties has long been recognized by the OECD:106

A mediator's role may offer an opportunity for the competent authorities to view a specific case, or the MAP process itself, from a much different perspective. This perspective, ..., may illuminate elements of a case or of the MAP process that are not perceptible when viewed from the standpoint of an administration defending an adjustment or one that is being asked to provide relief.

In a digital setting, it could be envisaged that once the parties feed the facts and the issues of a dispute into the AI, the latter can conduct a comprehensive and critical review of all of the relevant treaties, statues, case laws, and scholarly opinions to derive an amicable solution. Competent authorities may also elect to consult the AI mediator unilaterally so as to avoid the pressure associated with bilateral or multilateral consultations.

\subsection{Interim conclusion}

It can be seen from the above analysis that digitalization helps to economize all three types of transaction costs for the ITDR process. It is worth noting that while the analysis focuses on the MAP, the conclusion also applies to tax arbitration. Indeed, the topic of digital justice originated from and still centers on adjudicative settings such as litigation and arbitration. In short, tools such as online filing, online notification and videoconferencing all help to save procedural costs for both parties and adjudicators; and the use of an AI expert system may help to save the time and effort in relation to fact finding and legal research. Therefore, digitalization represents a promising direction for the entire ITDR process. This may be particularly true for developing and least developed countries where competent authorities face considerable resource constraints.

106 OECD, MEMAP, supra n. 21, at 28. 


\section{SPECIAL CASES FOR DIGITAL ITDR}

\subsection{Digital capability of tax administrations}

One concern about general digital justice is that part of the population may not be able to effectively handle ICTs, due to their incapacity or lack of resources. ${ }^{107}$ As a result, digital justice may, on balance, lead to a denial of justice for such a disadvantaged group. Nevertheless, tax authorities across the world are generally going digital and are hence more prepared to embrace digitalization compared with many other public or even private sectors. ${ }^{108}$ Digitalization of tax administration spans a wide spectrum such as: (i) e-file whereby a standard economic form is used for filing tax returns; (ii) e-assessment for which tax administrations apply data analytic techniques to assess tax without the need for tax forms; and (iii) e-settlement regarding when the disputes between the taxpayers and relevant tax administrations can be resolved online. ${ }^{109}$ Since 2016, the OECD has further undertaken exploring how tax compliance can be enhanced by implementing the latest developments in information technologies such as mobile platforms, cloud- computing, and big data. ${ }^{110}$

The high digital-capabilities of tax administrations arise from the fact that even merely for revenue purpose, these bodies need to understand business, which has been significantly transformed by IT. ${ }^{111}$ Indeed, addressing the tax challenges arising from digitalization of the economy occupies the top priority of the BEPS Project as is manifested in the blueprint. ${ }^{112}$

Nonetheless, tax authorities may still vary in their digital capabilities. As Mr. Mukhisa Kituyi, the Secretary-General of UNCTAD, notes, while the world as a whole benefits from digital economy, the road to e-commerce for developing countries is still 'riddled with potholes'. ${ }^{113}$

107 Civil Justice Council, Online Dispute Resolution for Low Value Civil Claims, 26-27,

https://www.judiciary.uk/publications/online-dispute-resolution-for-low-value-civil-claims-2/ (accessed 4 Apr. 2019).

108 EY, Tax Authorities Are Going Digital: Stay Ahead and Comply with Confidence,

https://taxinsights.ey.com/archive/archive-articles/tax-administration-continues-to-go-digital.aspx (accessed 13 Apr. 2019).

109 Ibid.

110 See OECD, Technologies for Better Tax Administration: A Practical Guide for Revenue Bodies (OECD Publishing2016).

111 Dimitropoulou, Govind \& Turcan, supra n. 7, at 856.

112 OECD, Action 1 - OECD BEPS, https://www.oecd.org/tax/beps/beps-actions/action1/ (accessed 27 Aug. 2019); OECD, Tax Challenges Arising from Digitalisation-Report on Pillar One Blueprint: Inclusive Framework on BEPS, supra n. 3.

113 M. Kituyi, Unctad.Org | The Digital Divide Is Impeding Development, https://unctad.org/en/pages/newsdetails.aspx?OriginalVersionID=1896 (accessed 6 Apr. 2019). 


\subsection{Frequency of tax disputes}

Digital justice requires robust, secure, and reliable technology to operate. More often than not, a bespoke ICT system is needed for a particular dispute-resolution setting. ${ }^{114}$ Accordingly, the setup and maintenance of a digital-justice system may incur considerable expenses that can only be justified by a large volume of disputes to be dealt with through it. ${ }^{15}$ In eBay, 60 million transaction-related disagreements are resolved each year through ODR. ${ }^{116}$ The use of ICTs in many domestic courts can also be justified by the heavy caseload jamming the judicial systems. ${ }^{117}$

Tax disputes are highly recurrent. For illustration, since 1995, approximately 600 disputes have been brought to the WTO. ${ }^{118}$ From 1972 to June 2020, 768 cases were registered under the ICSID. ${ }^{119}$ By contrast, in 2019 alone, the OECD members reported 2,690 new MAP cases. ${ }^{120}$ Note that the WTO consists of 164 members, ${ }^{121}$ and the ICSID of 163 members, ${ }^{122}$ whereas the OECD MAP statistics cover around 100 jurisdictions. ${ }^{123}$ The drastic difference in the volume of disputes between tax regimes and trade/investment regimes is by no means accidental. Specifically, trade/investment disputes largely arise from active state measures such as trade protectionism policy or confiscation of foreign investment, which are relatively rare. By contrast, tax disputes typically arise from divergent interpretation by different competent authorities in the day-to-day application of tax treaties that never seek to assimilate national tax laws but only to regulate the interface between those domestic rules. ${ }^{124}$ The high frequency of tax disputes has two major implications: justifying the setup costs of a digital ITDR and highlighting the value of the ICT-based case

\footnotetext{
114 Civil Justice Council, Online Dispute Resolution for Low Value Civil Claims, supra n. 107, at 10.

115 Mania, supra n. 70, at 78.

116 Civil Justice Council, Online Dispute Resolution for Low Value Civil Claims, supra n. 107, at 11.

117 Reiling, supra n. 74, at 81-82.

118 WTO | Dispute Settlement - Dispute Settlement Activity - Some Figures, , https://www.wto.org/english/tratop_e/dispu_e/dispustats_e.htm (accessed 3 Oct. 2019).

119 ICSID, The ICSID Caseload Statistics (Issue 2019-1) 7,

https://icsid.worldbank.org/en/Pages/resources/ICSID-Caseload-Statistics.aspx.

120 OECD, Mutual Agreement Procedure Statistics for 2019 (OECD) <

https://www.oecd.org/tax/dispute/mutual-agreement-procedure-statistics.htm > (accessed 20 January 2021).

121 WTO $\mid$ About the Organization, https://www.wto.org/english/thewto_e/thewto_e.htm (accessed 13 Apr. 2019).

122 ICSID, Database of ICSID Member States,

https://icsid.worldbank.org/en/Pages/about/Database-of-Member-States.aspx (accessed 20 Jan. 2021).

${ }^{123}$ OECD, 2019 MAP Statistics per jurisdiction (OECD)

https://www1.compareyourcountry.org/map-statistics/en/0/2288+2289+2290+2291+2292+2293+2294/default (accessed 20 January 2021).

124 R. M. Kysar, Interpreting Tax Treaties, 101 Iowa L. Rev. 1387, 1411 (2015); T. Rixen, From Double Tax Avoidance to Tax Competition: Explaining the Institutional Trajectory of International Tax Governance, 18 Review of InTERnational Political Economy 197, 206 (2011); K. Vogel, Double Tax Treaties and Their Interpretation, 4 INT'L TAX \& BUS. LAW 1, 22 (1986)
} 
management system.

\subsection{Recent reform of ITDR and digitalization}

Based on the transaction-cost analysis of the ITDR process and its digitalization, it is generally safe to state that the recent reform of the ITDR including, inter alia, the peer review process in Action 14, the EU directive, and the tax certainty process in the blueprint will all benefit from ICT tools. That being said, this section will further highlight that both the peer review process and the tax certainty process in the blueprint particularly lend themselves to the benefits of digitalization. This is true even though the two mechanisms reflect somehow opposite approaches to the ITDR reform - the peer review process reflects a soft-law approach, whereas the panel process under blueprint embodies some legalistic elements.

\subsubsection{Peer review process}

On one hand, the peer review process is highly structured involving numerous steps with a stringent timeframe for each of the steps. ${ }^{125}$ These steps, if conducted manually, would impose heavy workloads on the manpower undertaking the tasks, and are quite susceptible to human errors. On the other hand, the process presents a high level of programmability in terms of structured schedules and standard formats. It follows that the workflow can be more easily coded into computer language and thus automated by using ICT tools.

\subsubsection{Tax certainty process in the blueprint}

As was mentioned above, the blueprint recommends the use of digital means of communication in its tax certainty process. ${ }^{126}$ Arguably, this proposal is made not only as a response to the pandemic, but also due to the particular hallmark of the process, i.e. its multilateral character. This multilateralism may contribute to the further increase of transaction costs for the dispute prevention and resolution process. Specifically, as the number of parties increases, it would become more difficult to monitor any of the competent authorities. Moreover, there may be more challenges for the parties to find a commonly accepted solution to solve their distributive conflict, thereby reinforcing the risk of a bargaining impasse. The administrative costs of a

\footnotetext{
125 OECD, BEPS Action 14 on More Effective Dispute Resolution Mechanisms Peer Review Documents, supra $\mathrm{n}$. 18 , at 27.

126 See S. 1 above.
} 
multilateral MAP would also increase because it is more troublesome to coordinate and manage the conduct of multiple parties in the process. In this connection, ICT tools may play a greater role in economizing the tax certainty process in the blueprint.

At a more advanced level, the AI-based digital tools may aid the competent authorities and the panels to decide on the substantive aspects of Amount A cases including, inter alia, the tax base, the result of the implementation of the formula, the paying entities, and any other feature of the new taxing right. ${ }^{127}$ On the one hand, instituting Amount A and Amount B reflects the policymakers' intention to implement the new taxing right in a formulaic, simplified, and structural manner. On the other hand, numerous commentators have already predicted that the implementation of Amount A could be extremely complicated and contentious. ${ }^{128}$ Arguably, digitalization is the most conducive to tasks that are both programmable and complicated.

\section{DIGITAL ITDR IN PRACTICE: EXAMINATION OF PEER REVIEW REPORTS}

\subsection{Overview}

As Table 11 (see the annexed table) shows, out of 69 peer review reports, peers and/or the assessed jurisdictions in 31 reports either applauded the benefits of electronic means of communication including email, conference call, videoconferencing, etc. or suggested more use of such means. At least two reports explicitly mentioned that the use of mail by post had caused delays to their ITDR processes. ${ }^{129}$ One exception is the Report on France: a peer proposed to organize video conferences with the French competent authority which replied that it preferred to have audio-conferences instead of video-conferences for technical reasons. ${ }^{130}$

Several countries report that their competent authorities have ICT-based case management systems in place for the MAP process. ${ }^{131}$ For example, Spain reported

\footnotetext{
127 OECD, Tax Challenges Arising from Digitalisation-Report on Pillar One Blueprint: Inclusive Framework on BEPS, supra n. 3, at para.17.

128 S. Greil \& T. Eisgruber, Taxing the Digital Economy: A Case Study on the Unified Approach, 49 INTERTAX (2021); A. P. Dourado, The OECD Unified Approach and the New International Tax System: A Half-Way Solution, 48 IntertaX 3 (2020); M. F. de Wilde, On the OECD's 'Unified Approach' As Frankenstein's Monster and a Dented Shape Sorter, 48 INTERTAX 1 (2020).

129 OECD: Action 14 - OECD BEPS, supra n.17, reports on Chile (para.125) and South Africa (para.126).

${ }_{130}$ Report on France (para.116).

131 Reports on Canada (para.136), Belgium (para.91), Finland (para.106), Greece (para.115), India (para.142), Ireland (para.121), the Netherlands (para.83), Portugal (para.118), Spain (paras 110, 111), and Switzerland (para.72).
} 
that the internal management system developed by its competent authority can track the completion of the milestones for each pending MAP case. In addition, if the other concerned competent authority causes a long delay, the Spanish competent authority will send a reminder, or communicate a list of pending cases with a specification of which competent authority should take what action on each individual case. ${ }^{132}$ In Canada, the Competent Authority Control Tracking System (CATS) allows its competent-authority staff to easily input and update data about the workloads and activities relating to MAP processes. The management level of the department can thus review file progress on an ongoing basis and be informed of any inabilities to meet its commitments on the timely resolution of MAP cases. The system also monitors the implementation of MAP agreements. ${ }^{133}$ The remaining jurisdictions, however, either do not have any case management system in place or do not specify whether their case management systems are ICT-based.

\subsection{Lack of decision-making function}

The current practice of digital ITDR mainly takes the form of digital communication and case management systems. Presumably, most competent authorities have also employed stand-alone ICT tools such as computers, internet and databases, albeit not explicitly mentioned in the reports. In contrast, the decision-making component of digital justice in terms of either analysing the facts and/or legal arguments for individual cases or identifying general factual or legal patterns of multitudes of cases is generally missing in the ITDR practice. This may result from the users' concern about the plausibility and credibility of the decision-making function undertaken through digitalization, as was discussed in Section 3.3 (3).

\subsection{Issue of confidentiality}

Concerns about confidentiality present another major hurdle to the promotion of digital ITDR. In the report on Japan, one peer noted that electronic communication with Japan's competent authority was challenging as Japan only accepted the transmission of confidential information by fax. The peer, therefore, suggested that Japan could be more open to using encrypted e-mails for MAP negotiation. ${ }^{134}$ In the report on the United States, peers also reported that the communication process may

\footnotetext{
132 Report on Spain (paras110, 111).

133 Report on Canada (paras 101,136).

134 Report on Japan (para.181).
} 
be slowed due to the US requirement that taxpayer identification data could only be exchanged by mail or fax. ${ }^{135}$

\subsection{Fragmented approach}

Tools of digital ITDR have been implemented in a somewhat fragmented manner. Specifically, the case management systems developed by competent authorities are mostly for the purposes of internal management. Canada explicitly reported that its CATS system was intranet-based and thus segregated from the internet. ${ }^{136}$ Even ICT-based communication systems such as encrypted email channels have been at most developed in a bilateral manner. A common platform specialized for the secured exchange of documents involved in the ITDR process has yet to be developed. The deficiency of this fragmented approach has already been exposed in peer review reports. For example, the peer review mechanism in Action 14 requires jurisdictions to provide timely and complete reporting of MAP statistics, pursuant to the agreed reporting framework. ${ }^{137}$ However, competent authorities compile their MAP statistics independently despite the fact that the MAP itself is a bilateral or even multilateral process. As a result, those authorities have to reach out to all of their treaty partners to match their MAP statistics. ${ }^{138}$ Such manual matching could be rather cumbersome, duplicative, and subject to human errors.

Arguably, this fragmented approach accounts for, at least partially, the underdevelopment of digital ITDR. In the absence of transnational coordination, individual countries may lack the incentive to invest in a digital system with algorithms that are more advanced or channels for information exchange that are more secured. Furthermore, if countries elect to develop such specialized systems in a bilateral or multilateral way, there could be duplicated investments leading to a waste of resources.

\subsection{Imbalanced development}

Related to the fragmented approach discussed above, there is also a significant imbalance in the development of digital ITDR. For example, while many countries are comfortable with using modern means of communication in MAP processes, many

\footnotetext{
135 Report on the US (para.123).

136 Report on Canada (para.136).

137 OECD, Making Dispute Resolution Mechanisms More Effective, Action 14 Final Report, supra n. 16, at 16.

${ }^{138}$ For instance, see Report on France (para.87).
} 
others are still using traditional mail to exchange confidential information. One country seems to have encountered some technical difficulties in handling videoconferencing technologies. ${ }^{139}$ The sophistication of the ICT-based case management system also varies from country to country. Many countries do not have such systems at all. It should be noted that a majority of the peer review reports examined in this research concern developed countries. Arguably, the imbalance of digital ITDR would be exacerbated when developing countries are also taken into account.

\subsection{Interim conclusion}

From the above analysis, it could be seen that various ICT tools have already been used in ITDR practice, and their benefits are widely recognized by member countries. Indeed, the wide attention paid by Member States to the use of ICT in the MAP process reflects a high degree of digital awareness among competent authorities. That being said, the reports also indicate a preliminary and imbalanced development of digital ITDR at this stage. Apparently, this discovery contradicts the argument that the ITDR process is particularly amenable to digitalization as compared to other international dispute resolution mechanisms. Two factors may explain this paradox. First, as the peer review reports reveal, the concern of confidentiality has hindered the wider use of digital means of communication. As section 3.3 points out, privacy and data protection constitute a major concern for digital justice. Secondly, MAPs have traditionally been operated in a decentralized manner, conducted by competent authorities without intervention from any central authority. Arguably, individual competent authorities may lack sufficient incentive to coordinate and advance the development of digital ITDR at the global level. Note that the two factors may be linked with each other: taxpayers and tax administrations may have less faith in the digital communication channels that are built on a decentralized or even ad hoc basis by individual competent authorities.

\section{ADDRESSING THE BARRIERS TO DIGITAL ITDR: A LIMITED MULTILATERAL SOLUTION}

While digital ITDR may become imperative due to the incidence of the pandemic, its success should not be taken for granted. Poorly designed digitalization of the ITDR

\footnotetext{
139 Report on France (para.116).
} 
may ultimately turn into an unpleasant or even bitter experience for taxpayers and tax administrations. This may in turn drive those users away not only from digital ITDR but also from the dispute resolution process in its entirety, thus leaving taxpayers double taxed. In this context, this part strives to build an institutional framework to facilitate the digital transformation of the ITDR process.

The deficiencies of the current development of digital ITDR examined in the above section, particularly with respect to the fragmented approach adopted by countries, all point to the necessity of some transnational coordination in this issue area. In particular, a common digital platform is envisaged to connect the digital ITDR systems of participating countries. This platform would be mandated to compile the member countries' ITDR statistics that would be automatically retrieved from the case management system of individual countries. It could also be used to facilitate the peer review process endorsed in BEPS Action 14. Going further, digital means of communication such as an encrypted email channel and audio- or videoconferencing technologies would be built into this platform so that competent authorities may avail themselves of such technologies rather than building their own channels from scratch. At the most advanced level, this international platform can perform or at least experiment on the more entrepreneurial functions of digital ITDR such as the 'pattern research' on multitudes of cases and the project of AI mediation or AI arbitration.

At first sight, the UN seems to be the best candidate for developing the aforementioned digital platform, not in the least for the organization's wide representation among countries. Indeed, the UN handbook envisages the creation of such a type of platform regarding the digitalization of the MAP. This common platform may involve the use of secure clouds or shared software. ${ }^{140}$ However, these authors take the view that the OECD is as tenable as if not better than the UN in shouldering the task. First, the OECD has somehow outstripped the UN during the last few decades in becoming the leading forum for global tax dialogue and collaboration, particularly with respect to the ITDR process, manifested in the BEPS Action 14. ${ }^{141}$ Secondly, the recent BEPS Project led by the OECD has already involved or at least planned the development of certain multilateral data exchange platforms for tax administration purposes, such as those for automatic information

\footnotetext{
${ }_{140}$ UN: Dispute Avoidance and Resolution Handbook (Projected Framework): Chapter 5: Tax Treaty Mechanisms to Resolve Cross Border Tax Disputes: The Mutual Agreement Procedure, supra n. 5, at para.215. ${ }_{141}$ R. T. Kudrle, The OECD and the International Tax Regime: Persistence Pays Off, 16 Journal OF Comparative Policy ANALysis: Research AND PRACTice 201 (2014).
} 
exchange, ${ }^{142}$ peer review process, ${ }^{143}$ and country-by-country reporting, respectively. ${ }^{144}$ One particular concern may be that the OECD is less formal than the UN. Nevertheless, this very flexibility may have indeed contributed to the OECD's greater success in leading the global collaboration in tax agendas as compared to the UN. ${ }^{145}$ As to the representation issue, the endorsement of the G20 regarding the BEPS Project may have significantly enhanced the legitimacy of the OECD in promoting a global digital platform for the ITDR process. ${ }^{146}$ That being said, the UN and other international or regional organizations such as the EU may still play a significant role in developing and promoting principles or standards of digital ITDR as the EU has done in developing guidelines in digital justice. ${ }^{147}$

Notwithstanding the advantages of the institutional approach as argued above, the digitalization of the ITDR need not be carried out in a top-down manner. Specifically, while the launch of a common digital platform should principally be undertaken by a global institutional body, the development of digital case management systems could be and sometimes should be undertaken by individual countries. This is because, unlike the common platform, a case management system should be customized to the digital capability, legal, and cultural environment, as well as other special conditions of a particular tax authority. The analysis of the peer review reports has further shown that a number of countries have already had their own ICT-based case management systems in place - it might be irritating for these countries to switch to an entirely new system. Even for the part of digital ITDR that has more public quality, such as the digital communication channels, there is no need for such functions to be centralized into a single institution. Arguably, a centralized digital communication system may be more vulnerable to the risk of information leakage or hacking, thereby putting the confidentiality of a dispute resolution process under risk. This type of concern may be compounded as the centralized forum covers more countries with drastically different values, regimes, and development statuses. Therefore, states with such concerns should be entitled to partner with fellow countries that they put the most trust in or

\footnotetext{
142 OECD, Standard for the Automatic Exchange of Financial Account Information in Tax Matters: Implementation Handbook, para.5 (OECD Publishing 2018).

143 OECD, BEPS Action 14 on More Effective Dispute Resolution Mechanisms Peer Review Documents, supra $\mathrm{n}$. 18, at para.7.

144 OECD, Transfer Pricing Documentation and Country-by-Country Reporting, Action 13 - 2015 Final Report 45 (OECD Publishing 2015).

145 S. E. Malamis \& Q. Cai, International Tax Dispute Resolution in Light of Pillar One: New Challenges and Opportunities, 75 BULLETIN FOR INTERNATIONAL TAXATION, 15 (2021).

146 Ibid. at 15; J. Zhu, G20 Institutional Transition and Global Tax Governance, 29 THE PACIFIC REVIEW 465 (2016).

147 See S. 3.3 above.
} 
have the closest tie with fpr developing a more closed multilateral solution to digital ITDR. Under this decentralized institutional framework, intergovernmental organizations, such as the UN and the OECD, would still play a central role in shaping the most fundamental aspects of digital ITDR enumerated as follows:

- Development and maintenance of the common digital platform envisioned above, particularly in relation to the peer review process;

- Promulgation of guidelines on digital ITDR and the identification of best practice in this domain;

- Provision of technical or financial assistance to those countries with low capacity.

Those more advanced components of digital ITDR attached to the common platform, such as an AI-expert system, can be operated on an opt-in basis so that countries still retain significant control on the implementation of such components.

\section{CONCLUSION}

The Covid-19 pandemic highlights the imminence of a systematic reflection of digital ITDR which seems to be becomig an imperative for tax lawyers. Nonetheless, it would be a mistake to consider that digital ITDR draws its legitimacy mainly from this health crisis. Independent of the pandemic, digitalization has already presented enormous potential in strengthening the ITDR process, particularly in addressing, or at least mitigating, the most fundamental deficiencies that are inherent to the process, i.e., agency problem, bargaining difficulty, and administrative burden. Furthermore, the key characteristics of tax disputes and the resolution process also present strong cases for the digitalization of the ITDR process compared with many other types of dispute resolution. That being said, the analysis of peer review reports has uncovered several critical barriers to the full implementation of digital ITDR. These barriers will not be automatically eliminated simply because the pandemic would generally spur the process of digitalization, but rather warrant some deliberate institutional design on digital ITDR. In this connection, a multilateral forum was proposed to coordinate national policies and practices on the subject while, at the same time, each country retains considerable leeway in shaping this system.

\section{Annex}

Table: Summary of peer review reports regarding digital ITDR 


\begin{tabular}{|c|c|}
\hline Country & Comments on the use of ICT in the MAP process \\
\hline \multicolumn{2}{|l|}{ Andorra } \\
\hline \multicolumn{2}{|l|}{ Argentina } \\
\hline Australia & $\begin{array}{l}\text { The use of email increases efficiency (para.152); } \\
\text { Suggested more use of teleconferencing (para.155). }\end{array}$ \\
\hline Austria & $\begin{array}{l}\text { Digital means of communication increases efficiency (para.112); } \\
\text { Suggested finding new and secure electronic means to exchange information (para.114) }\end{array}$ \\
\hline \multicolumn{2}{|l|}{ The Bahamas } \\
\hline Belgium & $\begin{array}{l}\text { Suggested periodic use of conference call; suggested the use of secured email to improve turnaround } \\
\text { time (para.114); }\end{array}$ \\
\hline \multicolumn{2}{|l|}{ Bermuda } \\
\hline Bulgaria & $\begin{array}{l}\text { Suggested that further use of communication via email and telephone calls would help accelerate the } \\
\text { timeframes needed to resolve MAP cases (para 117) }\end{array}$ \\
\hline Brazil & $\begin{array}{l}\text { Suggested that the use of a secure electronic communication system (and the use of emails) could } \\
\text { help avoid delays in responses (paras } 22,95,113,125 \text { ) }\end{array}$ \\
\hline \multicolumn{2}{|l|}{$\begin{array}{l}\text { British Virgin } \\
\text { Island }\end{array}$} \\
\hline \multicolumn{2}{|l|}{$\begin{array}{c}\text { Brunei } \\
\text { Darussalam }\end{array}$} \\
\hline Canada & Suggested more use of conference call (para.109) \\
\hline \multicolumn{2}{|l|}{$\begin{array}{l}\text { Cayman } \\
\text { Islands }\end{array}$} \\
\hline Chile & $\begin{array}{l}\text { Chile attributed the delay a peer had experienced in a MAP case to the use of mail via regular post. It } \\
\text { therefore suggested more use of email (para.125). }\end{array}$ \\
\hline $\begin{array}{c}\text { China } \\
\text { (People's } \\
\text { Republic of) }\end{array}$ & $\begin{array}{l}\text { Suggested that the use of encrypted emails helped the speed-up of the process and proved to be an } \\
\text { efficient way to exchange documents (paras } 138,180,189 \text { ) } \\
\text { Close communications by way of telephone, email and fax, etc., prior to face-to-face meetings can } \\
\text { be beneficial (para. 168) }\end{array}$ \\
\hline \multicolumn{2}{|l|}{ Colombia } \\
\hline Croatia & Suggested the use of safe electronic means (para.129) \\
\hline Curacao & $\begin{array}{l}\text { Suggested that contacts with Curaçao's competent authority is smooth, most of which is via email } \\
\text { (para. 116) }\end{array}$ \\
\hline \multicolumn{2}{|l|}{$\begin{array}{c}\text { Czech } \\
\text { Republic }\end{array}$} \\
\hline Denmark & Suggested more use of email and conference call (para.143) \\
\hline \multicolumn{2}{|l|}{ Estonia } \\
\hline \multicolumn{2}{|l|}{$\begin{array}{l}\text { The Faroe } \\
\text { Islands }\end{array}$} \\
\hline Finland & \\
\hline
\end{tabular}




\begin{tabular}{|c|c|}
\hline France & Suggested more use of email (para.100); propose to use video conference (para.116) ${ }^{148}$ \\
\hline Germany & $\begin{array}{l}\text { Suggested more use of conference call (para.148); suggest more use of email; Germany raised the } \\
\text { issue of information security in digital communication(para.149) }\end{array}$ \\
\hline Greece & Suggested modern means of communication more frequently (para.148) \\
\hline Guernsey & $\begin{array}{l}\text { Suggest MAP negotiations made via regular phone and electronic correspondence in the first } \\
\text { instance, as an efficient, practical and suitable alternative to face-to-face meetings (para 119) }\end{array}$ \\
\hline \multicolumn{2}{|l|}{$\begin{array}{l}\text { Hong Kong, } \\
\text { China }\end{array}$} \\
\hline \multicolumn{2}{|l|}{ Hungary } \\
\hline \multicolumn{2}{|l|}{ Iceland } \\
\hline India & $\begin{array}{l}\text { Recommended more use of regular email and teleconference, which has expedited the process (paras } \\
171,179)\end{array}$ \\
\hline Indonesia & Its MAP unit is adopting electronic modes of communications (paras 171, 172) \\
\hline Ireland & Suggested frequent use of email and conference call (para.151) \\
\hline \multicolumn{2}{|l|}{ Isle of Man } \\
\hline \multicolumn{2}{|l|}{ Israel } \\
\hline Italy & $\begin{array}{l}\text { Suggested more use of (video) conference call (para.132); suggest more use of electronic means of } \\
\text { communication to exchange confidential data (para.134) }\end{array}$ \\
\hline Japan & Suggested more use of videoconferencing and email. (para.179) \\
\hline \multicolumn{2}{|l|}{ Jersey } \\
\hline \multicolumn{2}{|l|}{ Korea } \\
\hline \multicolumn{2}{|l|}{ Latvia } \\
\hline \multicolumn{2}{|l|}{ Liechtenstein } \\
\hline Lithuania & Regular contact via post or electronic means \\
\hline \multicolumn{2}{|l|}{ Luxembourg } \\
\hline \multicolumn{2}{|l|}{ Macau (China) } \\
\hline \multicolumn{2}{|l|}{ Malta } \\
\hline \multicolumn{2}{|l|}{ Mexico } \\
\hline Monaco & \\
\hline
\end{tabular}

148 As to this point, France replied that it preferred to use audio-conference instead of video conference for technical reasons (para.116). 


\begin{tabular}{|c|c|}
\hline \multicolumn{2}{|l|}{ Morocco } \\
\hline \multicolumn{2}{|l|}{$\begin{array}{l}\text { The } \\
\text { Netherlands }\end{array}$} \\
\hline New Zealand & Suggested more use of email (para.139) \\
\hline \multicolumn{2}{|l|}{ Norway } \\
\hline Poland & Suggested more use of email (para.127) \\
\hline Portugal & Suggested more use of email (para.153) \\
\hline Romania & $\begin{array}{l}\text { Suggested more use of email (para.132); do not regard telephone conferences as efficient, due to the } \\
\text { language difference (para.130) }\end{array}$ \\
\hline \multicolumn{2}{|l|}{$\begin{array}{c}\text { Russian } \\
\text { Federation }\end{array}$} \\
\hline \multicolumn{2}{|l|}{ San Marino } \\
\hline Saudi Arabia & $\begin{array}{l}\text { The competent authority is working towards automating communication procedures so that all } \\
\text { communication with taxpayers will be done via electronic means (para 59). }\end{array}$ \\
\hline \multicolumn{2}{|l|}{ Serbia } \\
\hline \multicolumn{2}{|l|}{ Singapore } \\
\hline \multicolumn{2}{|l|}{$\begin{array}{c}\text { Slovak } \\
\text { Republic }\end{array}$} \\
\hline Slovenia & Email and conference calls increased efficiency (para.151) \\
\hline South Africa & $\begin{array}{l}\text { South Africa noted that its peers' use of mail by post rather than electronic channels caused delays } \\
\text { (para.126) }\end{array}$ \\
\hline Spain & Suggested more use of email (para.149) \\
\hline Sweden & Suggested more use of video conference (para.118) \\
\hline \multicolumn{2}{|l|}{ Switzerland } \\
\hline \multicolumn{2}{|l|}{ Tunisia } \\
\hline \multicolumn{2}{|l|}{ Turkey } \\
\hline \multicolumn{2}{|l|}{$\mathrm{UK}$} \\
\hline USA & $\begin{array}{l}\text { US raised the issue of information security in digital communication (para.123); suggest more use of } \\
\text { conference calls or videoconferencing (para.127) }\end{array}$ \\
\hline
\end{tabular}

Derived from Stage 1 peer review reports, https://www.oecd.org/tax/beps/beps-actions/action14/ (accessed 28 Jan. 2021). 